\title{
Indigenous and Western Medicines in Colonial South India: Nature of Discourses and Impact
}

\author{
Kanagarathinam D V*
}

(Received 22 September 2017; revised 05 February 2018)

\begin{abstract}
The paper attempts to study nature of the contest between indigenous and western medicines in the public sphere during the late nineteenth and the early twentieth century. Western medicine was introduced initially for benefit of Europeans in India and later extended to Indian population as a tool of empire. Gradually it marginalised indigenous medicine with help of state power and colonised indigenous bodies to get cultural domination. Revitalisation of Indian medicines started with through professionalisation, systematisation, standardisation and their important aspects were exposed in print media as a tool to contest against the hegemony of western medicine in the public sphere. Numerable tracts, pamphlets, journals and books of indigenous medicine were published to counter the hegemony of western medicine. Here the focus is on discourses of physicians of indigenous and western medicines, published in the print media in colonial south India, and how the former made efforts to counter the hegemony of western medicine.
\end{abstract} South India

Key words: Hegemony, Indigenous medicines, Western medicine, Discourses and Colonial

\section{INTRODUCTION}

The British Medical Journal in September, 1923 published a response of practitioners of western medicine against a report of the Committee of indigenous medicine chaired by Muhammad Usman Sahib Bahadur to Madras Government for the development of indigenous medicines as follows:

In the last hundred years science has emerged from the metaphysical stage into the clear light of positive knowledge, and if the Madras Government has the interests of the Indian people genuinely at heart, it will expand its energies in planting modern science in the country, by the agency of scientists and teachers trained in western methods, instead of endeavouring to stimulate the belated indigenous systems into renewed activity. There are many indications in the report that Ayurvedists feel the need of European methods - the microscope, bacterial technique, etc. What they really need is an altered scientific outlook... The Madras Government is apparently at the parting of the ways. It will be interesting to see whether it decides to set things moving in the path of progress by the encouragement of European scientists, or pushes the country back into the old metaphysical rut (The British Medical Journal, 1923, pp. 479-780).

The Usman Committee recommended the synthesis and assimilation of western and indigenous medical 'systems' to bring out a 'unified and integrated whole'. The recommendation received severe criticism from practitioners of western medicine who continuously produced a negative criticism on indigenous medicines and portrayed their 'unscientific' nature. Western medicine was introduced to Indian subcontinent to protect the health of Europeans. But it was used as a 'tool' to

\footnotetext{
* Assistant Professor, Department of History, School of Social Science and Humanities, Central University of Tamil Nadu, Thiruvarur, Tamil Nadu, Email: kaviart86@gmail.com
} 
colonise the Indian mass while introducing to combat epidemics and other dreadful diseases. According to scholars, western medicine was used as a mere justification for the supremacy of British rule. Colonial medicine acted as an 'ideological tool of empire' along with representing the blending nature of 'humanitarian concern and social control' (Bala, 1991 and Arnold, 1993). The dialogue and relationship between western and indigenous medicines was not linear process. During the period between the $16^{\text {th }}$ and early $19^{\text {th }}$ century, practitioners of western and indigenous medicines mutually respected and helped each other to advance their respective medicines because both shared the common theory of disease causation (Linschoten, 1885 and Orta, 1913). It moved from 'acceptance and appreciation of indigenous medicines' by practitioners of western medicine in the seventeenth and eighteenth centuries to 'scientific scepticism' in the nineteenth century. Scientific scepticism enlarged the gulf between the 'systems' and pushed the indigenous medicines from the boundary of rational, scientific and legitimate medicines into irrational, unscientific, dangerous and superstitious category leading to the withdrawal of support of the colonial government as reflected in the closure of the Native Medical Institution (Ramasubban, 1988; Harrison, 1994 and Bhattacharya, 2011). The emergence of hospital medicine (western medicine) having a new form of knowledge based on anatomy and physiology and newer practices of medical intervention marginalised indigenous medicines as primitive and outdated systems (Goodeve, 1837 and Bhattacharya, 2014). Indigenous medical knowledge was evaluated by western medical techne and episteme which ultimately devalued and delegitimised (Sen and Das, 2011).

Due to the marginalisation, practitioners of indigenous medicines were very keen to find out ways to modernise their medicines. They adopted different methods like professionalisation, institutionalisation and standardisation of medicines to legitimise their knowledge of medicine in the public sphere. These processes were named as revitalisation movement in the cultural sphere. 'Revitalization Movement' is a term used by Anthony F C Wallace, an anthropologist, to explain cultural changes in the society. He defined it as a deliberate, organized, conscious effort by members of a society to construct a more satisfying culture (Wallace, 1956). When the present culture of a society fails to deliver a satisfying stress reliving mechanism, the members of that society start to find out new cultural practices to maintain equilibrium of stress (Wallace, 1956). Stress is defined by him as a condition in which some or the whole of the social organism is threatened by more or less serious damage. Stress might be invention, war, epidemic or cultural distortion. After the advent of colonialism, indigenous culture was threatened and distorted by the colonial government and western culture in each and every aspect in which the role of western medicine was prominent. Roy Macleod argued that "western medicine - a cultural force," acted both as a cultural agency in itself and as an agency of western expansion (Macleod, 1989, p. 1 and Panikkar, 2009, p. 169). When western medicine tried to establish its superiority over indigenous medicines with the help of the state power and the support of newly emerged Indian western-educated intellectuals, it marginalised and delegitimised indigenous medicines. The practitioners of indigenous medicines felt a sense of insecurity as they anticipated an unequal confrontation with western medicine. In this context, practitioners of indigenous medicines started to look critically at the state of their medicine and planned a movement, both revivalistic and vitalistic, which could revive the authority of ancient classical texts and at the same time, borrow cognisance of aspects of western medicine such as anatomy and surgery. The systematisation of knowledge, institutionalisation of training and standardisation 
of medicine was also undertaken following the line of western medicine (Panikkar, 2009, p. 15).

The revitalisation movement is a culturalintellectual movement which emerged in Colonial India, especially in the three British Presidencies: Bengal, Bombay and Madras. Practitioners of indigenous medicines initiated number of measures to vitalise indigenous medicines and combat western superiority and simultaneously, closely maintained links with all India level organisations such as Ayurveda Mahamandal. A number of protagonists like Ganga Prasad Sen, Gangadhar Ray and Gananath Sen in Bengal, Shankar Shastri Pade in Maharashtra, D Gopalacharlu, Duraiswami Aiyangar, Narayana Iyengar, Achanta Lakshmipathi (A Lakshmipathi), Thriparangott Parameswaran Mooss, Paniyinpally Sankunni Varier (P S Varier) in Colonial South India and so on were deeply involved in regional as well as national level professional organisations of medical practitioners. The practitioners of indigenous medicines endeavoured to retrieve internal and external causes for the decline i.e. ignorance of practitioners, stagnation of knowledge, non-availability of medicine and contest against hegemony of western medicine in the public sphere. Practitioners of indigenous medicines initiated changes in these areas of traditional medicines by taking into account the knowledge and experience of western medicine. Moreover, this revival and revitalisation led to construction of a monolithic form of Ayurveda, weaned from inconsistencies and untenable concepts, and particularly, as free from magical and religious elements as possible. This period is called as the renaissance period of Ayurveda by the scholars (Meulenbeld, 1999, p. 2). However, some physicians opposed incorporating western medical knowledge into indigenous 'systems' and strived to revive ancient medicine.

During the late nineteenth and the early decades of the twentieth century, there was a fierce contest in the medical sphere. Western science and medicine were severely contested by indigenous intelligentsia in the public sphere. Indians accepted British laws without much fuss, but not their medicine (Kumar, 1997). When practitioners of western medicine criticised indigenous medicines in the public sphere through print media, practitioners of indigenous medicines also adopted the same tool to contest the superiority of western medicine. The range of debates between practitioners of western and indigenous medicines were from simple medical drugs and disease causation to germ theory and medical reports. The discourse between western and indigenous medicines was not mediated only by the political economy but also by race, culture, nationalism, religious feelings and other factors. Many scholars have worked on the revitalisation of indigenous medicines but not on the narratives and rhetoric of practitioners of indigenous and western medicines in the printed world. They only sought to understand the contest in the form of institutional changes brought about by practitioners of indigenous medicines. The discourse of resistance of indigenous medicines was conducted not only against western medicine but also against the colonial project of the hegemony of cultural consciousness.

The paradigm of contestation was extended in the sphere of discourse of indigenous science by scholars like Neshat Quaiser, Claudia Liebeskind, Gyan Prakash, Uma Ganesan and others (Bala, 1991; Gupta, 1998; Prakash, 2000; Quaiser, 2001; Liebeskind, 2002; Ganesan, 2010 and Das, 2012). David Arnold portrayed the construction of Hindu Science by western educated intelligentsia as a contest with western scientific 'modernity' (Arnold, 1999). According to Gyan Prakash, Hindu Science was constructed in a 'Hindu Sanskrit idiom' by the device of 'translation' and 'reinscription' to appropriate the scientific knowledge and universalist claims of western science. These reconstructions were codified by the scholars as '(re)invention of 
tradition' (Langford, 2002; Weiss, 2009 and Hardiman, 2009). The studies of Claudia Liebeskind and Neshat Quaiser revealed the discourse of Unani against the criticism of practitioners of western medicine and delineated its complex scientific constructions in the public sphere. They analysed how Unani medicine was being (re)shaped by hakims by asserting the scientific credentials of Unani and simultaneously criticising the rhetoric of universality and value neutrality of western medicine. These works pointed out how practitioners of indigenous medicines produced the rhetoric in the public sphere, to establish medical authority and antiquity for their respective medicines, and to what extent their medicine is scientific, rational and authentic. But, in the case of Ayurveda, Uma Ganesan, Kavita Sivaramakrishnan worked on the discourse of practitioners of indigenous medicines on themes like the history of Ayurvedic past, but did not deal with the rhetoric and constructions on drugs, anatomy, the debates on and responses to government reports etc. An extensive analysis of the discourses on various themes of resistance and constructions of practitioners of indigenous medicines such as germ theory, efficacy of indigenous drugs, anatomy and physiology has been put forward. The contest of indigenous medicines against western medicine was not a homogenous, undifferentiated process and produced identically by all the practitioners of indigenous medicines as a response; it was a matrix of complex and ambivalent production and the degree of 'hybridity', varied from one physician to another. This complexity and the ambivalent nature of discourses have been examined with caution. Besides, the particular as well as the shared modes of arguments of practitioners of indigenous medicines in the contest were analysed as well. It covers also the discourses of disease causation, efficacy of drugs, scientific nature, diagnostic techniques, surgery, anatomy and antiquity of indigenous and western medicines.

\section{Discourse on the Causation of Disease and Germ Theory}

There was a paradigm shift in the relationship between indigenous and western medicines after the emergence of new science of pathological anatomy and hospital medicine in Colonial India. By the end of the seventeenth century, a new development occurred in Europe in the field of anatomy and physiology, and it directed western physicians to look at the body in a fundamentally different manner from their Indian counterparts which created the gulf between western and indigenous medicines. European physicians critically looked at the conception of the body in indigenous medicines and reflected indigenous anatomical ignorance in their writings. However, the gulf of anatomical knowledge between western and indigenous medicines did not make the former to abandon the dialogue. But, during the end of the eighteenth century, the conception of disease was altered fundamentally by the new science of pathological anatomy, which had emerged from the Paris hospital. Now, western medicine located the diseases in a particular organ or tissue while indigenous physicians still believed general distempers affecting the whole body. This conceptual gulf widened the gap between indigenous and western medicines and appeared as unbridgeable (Harrison, 2001).

The genesis of the hospital medicine played a pivotal role in the relationship between western and indigenous medicines in Colonial India. The Calcutta Medical College (CMC 1835) acted as both an educational and a scientificclinical institution and was the centre of a new form pedagogy, as well as the apparatus for ushering in new form of knowledge of the body and newer practices of medical intervention (Sen and Das, 2011, p. 479). The practical knowledge about structures and functions of interiors of body parts and organ localisation of diseases were firmly established by autopsy. Western medicine with a new form of techne and episteme emerged 
as a hegemonic medicine and attempted to marginalise indigenous medicines in the political and social life (Bhattacharya, 2013). Goodeve's (1837) introductory lecture to the students of CMC reflects the state of indigenous and western medicines at that time and superiority of western medicine over indigenous medicines. He stated about the causation of the disease in the indigenous systems of medicines as follows:

The medical art in India, such as it is, is founded upon no knowledge of anatomy, no principles of physiology. It is utterly devoid of all pathological research — objects which must necessarily form the basis of all scientific enquiries upon the subject. On the contrary, it consists of a set of dogmas, generally as ridiculous and injurious, as they are unintelligible, stating for example that all diseases are either of a hot or cold nature, or that they are produced by humours in the brain or in the liveropinions formed without any reference whatever to the actual condition of the organs or of their functions, either in a healthy or a diseased state.

Further he advised his students how to pursue the diseases in which he had given stress to pay strict attention to a morbid anatomy or pathology (Goodeve, 1837). The mid-nineteenth century onwards, humoral pathology was severely criticised by practitioners of western medicine in the public sphere (Koman, 1921, p. 3). In the late nineteenth century, western medicine and practitioners moved away from indigenous medicines. Particularly, the development of bacteriological research and emergence of new scientific ideas such as Robert Koch's discovery of cholera bacillus and Ronald Ross's identification of the mode of malaria transmission led the shift away from the environmental paradigm of disease causation which ultimately pushed indigenous medicines into the sphere of 'primitive' and 'outdated' 'system' from the perspective of practitioners of western medicine. The increasing professionalization of western medicine in Britain and India led to the demise of the humoral theory totally and the diagnostic methods based on it. Besides, practitioners of western medicine began to distance themselves from cultural and textual contexts in which the indigenous medicines were located (Bala, 1991, pp. 52-53). Further, this shift intensified discourses between practitioners of western and indigenous medicines in the public sphere (Arnold, 2002). When western physicians tried to establish their authority over indigenous medicines based on new scientific ideas and institutions, practitioners of indigenous medicines explained humoral theory in a scientific mode and situated germ theory within the matrix of Ayurveda.

The humoral theory of indigenous medicines was brought into forefront by the writings of Oriental scholars like H H Wilson and J F Royle. As to the nature of disease causation a 'single coherent theory' was not practiced in premodern India. In fact, indigenous medical 'systems' had multiplicity of theories for the causation of disease such as the tridosa-tattva (humoral theory), the pragyapradha-tattva (disease causation through 'violation of good judgement), the sapta-dhātu tattva (theory of seven 'bodily supports'), the theory of epidemics through the moral corruption of the monarch and theories of heredity, etc (Hymavathi, 1993 and Mukharji, 2013). Indigenous medical texts frequently carried more than one theory in the same texts. Often, these theories were partially reconciled with each other even within a single text and varied widely between different texts and authors. Before the revitalisation of indigenous medicines, a single theory that defined everything had not emerged. During the late nineteenth century, a single coherent theory based on humours (vāta, pitta and kapha) gained currency as the sole authority of indigenous medicines (Mukharji, 2013 and Attewell, 2013). Moreover, humoral theory was established as a fundamental theory of indigenous medicines during the debates between indigenous and western medicines.

Practitioners of western medicine attacked humoral theory as outdated and unscientific and 
at the same time promoted germ theory as the established one. Surgeon General of Bombay, Hooton criticised Ayurveda as standing on 'false theory' in his report on Civil Hospitals and Dispensaries in Bombay presidency. He attacked Ayurveda that it is based on erroneous theories and cannot bear comparison with the modern system of medicine attained on recent advances in science (Mukerjee and Sen, 1927, p. 159). Likewise, Lt. Colonel Harper - Nelson criticised the humoral theory of Ayurveda as empirical and unscientific. He pointed out:

Ayurveda is empirical and unscientific. The indigenous system is without even the rudiments of science, as they are largely based on the longdiscarded humoral theory. As regards diagnosis Ayurvedists do not know even the rudiments of clinical diagnosis with instruments and Laboratory. As for Treatment, they use some unknown nostrum (Mukerjee and Sen, 1928a, p. 42).

While practitioners of western medicine attacked and criticised humoral theory and projected indigenous medicines as unscientific, practitioners of indigenous medicines reacted in two ways such as discarding the germ theory and locating germ theory within the boundary of Ayurveda. In this process, practitioners of indigenous medicines (re) interpreted Sanskrit terms to equate western medical terms as well. For instance, Vishagacharyya Girindranath Mukerjee countered the views of Harper - Nelson and ousted bacteriology as a failed concept. He pointed out that theories of modern scientific medicine were cropping up now and then to be discarded after some years. The theory of bacteriology of allopathy which had replaced the old so called humoral theory fails to satisfactorily explain all diseases and had failed to produce a line of treatment which would successfully combat all diseases, though high hopes were entertained at one time regarding the efficacy of the various vaccines (Mukerjee and Sen, 1928, p. 43). Besides, he compared Allopathy and Ayurveda and said that Allopathy being based on the "pathology of infection' had got so few specifics - A specific was landed at one time only to be discarded after few years. Ayurveda being based on the 'pathology of constitution' treated specifically every symptom-complex presented by the patient, - the so called symptomatic treatment of diseases. Further he added that practitioners of Western medicine were trying to build a theory on the 'pathology of constitution' vis., the theory of symptomatic-endocrinology which was the nearest approach to the 'Tridosa theory' of Ayurveda (Muherjee and Sen, 1928, pp. 43-44). Thus, his writings rejected the germ theory and also reflected the superiority of Ayurveda.

While physicians like Girindranath Mukerjee, attacked germ theory, a group of indigenous physicians made subversive attempt to assimilate germ theory within the matrix of Ayurveda. They showed direct correspondence between canonical Ayurvedic texts and western medical discoveries regarding the knowledge of germs through which they tried to prove that ancient Rișis already had the knowledge of germs and their impact before the western discoveries. Many Ayurvedic physicians correlated Sanskrit terms with modern microorganisms from Ayurvedic texts (Aiyangar, 1921a, pp. 14-16; Iyengar, 1925a, pp. 4-5 and Iyengar, 1926a, pp. 1-3). For example, Kaviraj Gananath Sen presented evidences of germs from Ayurvedic texts such as Suśruta and Asțānga Hrdayam. He believed in the bacterial origin and the infective nature of certain diseases such as the eruptive fevers, leprosy, small-pox, tuberculosis etc. According to him:
All forms of leprosy (and some skin diseases) are not only due to the derangements of vāyu, pitta and kapha but are also of parasitic (micro- organism) origin.Various skin- diseases and Leprosy, Fever, Pulmonary consumption, Ophthalmia and Epidemic diseases borne by air and water are usually capable of transmission from one man to another. There are various fine organisms, which circulate in the blood and are 
invisible to the naked eye; usually these look like round bodies of copper colour and are without legs. They give rise to various forms of skin diseases etc. (Sen, 1916, pp. 26-28 and Shah, 2017)

Sen established that germs were powerless to cause disease unless the field was suitable for the growth of the seed. Ayurveda did not give primary role to germs which is given in western medicine today (Sen, 1920, pp. 101-103 and Usman, 1923, pp. 2-3). Like him, Physician Pandit Duraiswami Aiyangar (1919) interpreted the Sanskrit term rudhran as microbes (germs) of modern terms. He projected that the characteristic features of microbes and rudhrans of Sanskrit texts were identical. He affirmed that ancient texts proclaimed these rudhrans were responsible for the contagious diseases. Finally, he concluded that the ancient forefathers knew the concept of germs from the remote past (Aiyangar, 1919, pp. 133135). While a group of physicians correlate Sanskrit term with modern terms, some physicians attempted to re-establish theory of humour for disease causation along with situating germ theory within the boundary of Ayurvedic pathology. For instance, P S Varier explained the causation of disease as:

\begin{abstract}
Diseases are two kinds $n \bar{\jmath} j a$ and $\bar{a} g a n t u$. The former are those that are caused by conditions originating in the system itself while the latter are those caused by outside conditions such as bacteria, poison and violent pressure or concussion. The chief difference in the two kinds is that in the former the dosas are disturbed by internal causes and they become uncontrollable gradually, whereas in the latter the outside causes disturb the dosas all at once and the doșas has become uncontrollable all at once... Neither does the western theory that diseases are caused by minute organisms ultimately contradict this. For it is only to be understood that the minute organisms bring about the derangement of the three dosas which is the cause of the diseases (Usman, 1923, p. 215).
\end{abstract}

However, some practitioners of indigenous medicines opposed these sort of equations of the concept of Ayurveda with western medical concepts. For instance, K G Natesa Sastri,
Ayurvedic physician and teacher in Venkataramana Ayurvedic College, Madras published a text Kalyāni which is a repartee to the Gananath Sen's book Siddhānta Nidāna in which he opposed the equation of the concept of microorganism with Ayurveda. Further, he explained that the concept of krimis in Ayurveda was different from micro-organism of western medicine (Iyengar, 1947, pp. 189-190).

When practitioners of western medicine tried to marginalise indigenous medicines on the basis of germ theory, the response of practitioners of indigenous medicines were various kinds. While some physicians were projecting the failure of germ theory and the superiority of Ayurvedic theory of disease causation, others re-established humoral theory and tried to situate modern germ theory within the boundary of Ayurveda by correlating Sanskrit terms with western medical terms.

\section{Debates on the Effectiveness of Drugs: Indigenous vs Western Medicines}

Despite differences on the nature and effectiveness of drugs of western and indigenous medicines, practitioners of western medicine were very keen to incorporate indigenous drugs into British pharmacopeia to reduce the cost of import of drugs from Europe. From the advent of the Europeans into India, like Garcia da Orta, Sir William Jones, John Fleming William Roxburgh, and Whitelaw Ainslie were interested in the Indian medical plants. English East India Company sponsored the investigation of indigenous drugs to lessen its reliance on imported drugs. Some important works on Indian pharmacopoeia were Whitelaw Ainslie's Materia Medica of Hindoostan (1813) and Materia Indica (1826); George Playfair's Talifi-Sharifi, entitled, Indian Materia Medica (1833) and W B O'Shaughnessy's Bengal Pharmacopeia (1844) (Harrison, 2001, pp. 66-67 and Arnold, 2002, pp. 67-68). Indigenous 
medicines were procured from the bazaars by western medical hospitals due to unavailability of western drugs. As has been noted by Pratik Chakrabarti, the records of hospitals located in Madras city, during the eighteenth century, reflected the usage of bazaar medicines which showed that practitioners of western medicine depended on indigenous drugs for their treatments and accepted its reliability in curing diseases. He provided the instance of G Dunbar who reported his successful treatment of intermittent fevers in Ganjam by prescribing locally available drugs called 'Hindustanee Fever Pills' (Chakrabarti, 2006). However, practitioners of western medicine did not accept all indigenous drugs as worthwhile but they absorbed only such drugs which were considered as useful in specific remedies (Harrison, 2001, p. 67). English East India Company and the colonial government allocated funds to prepare pharmacopoeia of indigenous drugs. During the second half of the eighteenth century, several civil medical officers and Indian medical officers published pharmacopoeia of indigenous drugs continuously. Likewise, Indian version of pharmacopeia, entitled, The Pharmacopeia of India (1868) was prepared under the aegis of the colonial government (Harrison, 2001, p.52). Rachel Berger (2013, pp. 56-57) explained this process as follows:

\begin{abstract}
Indigenous drugs had been a part of tropical medicine from the point of contact between Europe and Asia and had an important role in framing public health policy for the EIC dating back to the eighteenth century. The creation of Indian Pharmacopoeias in the nineteenth century and the addition of Indian flora and fauna to the British Pharmacopoeia had created a systemic model through which indigenous knowledge could be incorporated into British medical and scientific thinking.
\end{abstract}

The colonial state continuously updated its knowledge of indigenous drugs through appointment of committees to find useful drugs to replace European imports. Apart from these process, the colonial government instructed to the medical department to use indigenous drugs as a substitute to western drugs (Bala, 1991, p.51). But, in the late nineteenth century, practitioners of western medicine moved away from indigenous medicines due to increasing professionalization in Britain and India and the rise of drug industry in Britain. In particular, they classified indigenous medicines as necessarily inferior (Bala, 1991, p. 52). For example, Udoy Chand Dutt pointed out about the drawbacks of indigenous medicines in his Materia Medica (1877) that sensible particles (substances of indigenous medicine) enter into minute details regarding their cooling and heating effects on the system, and their special influence on the humours which were supposed to support the machinery of life, namely, air, bile and phlegm and blood. According to him, these details were not the result of observation and experience but the outcome of an erroneous system of pathology and therapeutics (Dutt, 1877, p. IV). Similarly, M $\mathrm{C}$ Koman criticised the nature of indigenous drugs in his indigenous drug report. He said that Hindus employed numerous substances to prepare drugs which were dubious or trifling of virtue (Koman, 1921, p. 3). Moreover, practitioners of western medicine also sternly attacked the effectiveness of the indigenous drugs in the competitive market scenario. However, the colonial government and the hybrid practitioners of western medicine (Daktars) accessed indigenous drugs during the time of necessity. Madhuri Sharma delineated competition among various 'systems' of medicine to grab the space in the medical market in which practitioners of western and indigenous medicines employed different methods to attract the mass (Sharma, 2012, pp. 105-146). During the revitalisation of indigenous medicines, practitioners of indigenous medicines started to commodify indigenous drugs to meet the demands of the urban market like western medicine. Practitioners of indigenous medicines opened new manufacturing units and produced large number of drugs which varied from traditional ways of medical production. To compete in the medical market, 
they adopted techniques of entrepreneurs of western medicine such as advertisements, retail networks, social networks etc., (Sharma, 2012, pp. 105-146). Practitioners of indigenous medicines propagated the superiority of their drugs in the medical journals and simultaneously marginalised western medicine as impure and outside medicine while western medicine stood on its scientific authority.

Practitioners of indigenous medicines defamed western medicine as artificial medicine, full of harmful side effects while promulgating indigenous medicines as natural and complete alleviators of disease. They continuously compared that western medicine was symptomoriented whereas indigenous drugs were holistic medicines which treated diseases by regulating the humours. For instance, Pandit Narayana Iyengar, published articles about western and indigenous drugs consistently in his journal Vaidya Chandrika. His article, entitled, "Svadēsha Marundugal" (Indigenous Drugs) argued that western medicine dealt with symptoms of diseases without understanding causes. It tried to hide the symptoms by screening it behind the action of medicine and it would not cure completely. Also, when western drugs would cure one sort of disease, it would create other sort of diseases in the body that might be dangerous. Besides, he showed the example that Aspirin and Phenacetin bring symptoms under control and simultaneously affect the activity of the heart. But, indigenous drugs give importance to remove the root cause of diseases completely along with strengthening the immunity of the body (Iyengar, 1925c, pp. 35). His another article, entitled, 'Edu Uyarntadu' (Which is Superior) compared the nature of western and indigenous drugs. He projected that western drugs were artificial creations. The contents of western drugs mostly were chemicals synthesised in the lab and these chemicals were very harmful to the human body. On the contrary, Ayurvedic drugs were gift of nature like herbs and minerals and were biotic components of the environment which never produce side effects. Further, metals and minerals like iron and mercury were used in western medicine to prepare compound medicines but these medicines created negative impact on human system whereas practitioners of indigenous medicines also used the same poisonous substances to cure diseases without producing harmful effects due to the knowledge of purification of these elements which knowledge was absent in western medicine (Iyengar, 1925b, pp. 1-4). Likewise, P S Varier compared indigenous and western drugs and pointed out in his article that if ayurvedic drugs were taken even by mistake it would never cause any side effects and would improve the immunity of the body. But the same condition would not apply to western drugs which would even lead to death in some cases such as potasium iodide, sodium iodide and carbolic acid. Further, Varier warned that if one chose western drug for chronic diseases, it should be continued until death otherwise diseases would pop up again at the moment the drugs were stopped. Another problem of taking western medicine was that if used in long term, it would affect the internal organs bacause most of the drugs were prepared from chemicals. On the other hand, ayurvedic drug would never create any side effects even if it would use in the long term because all were made from the herbals (Varier, 1914, pp. 121-126).

Practitioners of indigenous medicines not only attacked western medicine generally, they also targeted particular western drugs for their side effects. They wrote separate articles regarding malaria, kala azar and pneumonia and their western drugs. For example, during the late $1800 \mathrm{~s}$ and first half of 1900s, malaria fever was the worst epidemic which afflicted 100 million lives annually and killed more than one million people per year in India. In 1892, the Government of India started to supply quinine on a large scale to meet the demand of poorer classes. The government 
endeavoured to increase the availability of quinine for villagers living in rural areas by 'Piece Packet' scheme - selling a single dose of quinine through post offices (Polu, 2012, pp. 82-85 and Roy, 2013, p. 68). In this scenario, quinine and salvarsan was promoted as a universal panacea for malaria fever by practitioners of western medicine. For example, J W D Megaw (1925, p. 585) compared western and Ayurvedic drugs and pointed out in the Indian Medical Gazette thus:

\begin{abstract}
Compare the advances which have been made by scientists in the discovery of new and potent remedies like the salvarsan group with those which have resulted from rummaging among the heaps of vaunted ancient drugs. It is not really surprising that the old drugs should yield such poor results; our present supply of remedies consists chiefly of substances which have been found by centuries of empirical use to have a certain value, and the reason why so many have been discarded is that they have not stood the test of observation and experience.
\end{abstract}

Finally, he concluded that no single Ayurvedic drug was equivalent to salvarsan and quinine of western medicine. To counter it, practitioners of indigenous medicines sternly attacked the usage of quinine and exposed its side effects. Innumerable indigenous drugs were provided instead of quinine for treating malaria fever such as nilavèmbu (andrographis paniculata), kōrai Kilañku (Cyperus rotundus), kaḍgu-rōhiṇi (Picrorrhiza kurro) and sēnthil kodi (Tinospora cordifolia). In the early part of the twentieth century, articles were published unremittingly in vernacular journals regarding malaria and quinine (Iyengar, 1927, pp. 1-4). Besides, they also used the perspectives of western physicians to support their attack on quinine. For instance, Ayurvedic physicians K Subramaniyam has written an article, entitled 'The Malaria - Vishamajvaram' in which he stated that practitioners of western medicine used quinine for malaria fever. But, quinine reacted negatively and produced side effects include flushing, ringing in the ears, headache, unusual sweating, vomiting, decreased hearing, blurred vision and temporary changes in colour vision instead of curing diseases. Indigenous medicines like nilavèmbu, kōrai kilañku, kadugurōhiṇi, pāppādagam, ạdāthōdai and vèmbu pațai were very powerful than quinine and they also would boost the immunity of the body rather than creating side effects (Sumbramaniyam, 1921, pp. 3-5). Pandit D Gopalacharlu (n.d, p. 50) had written in his advertisements as follows:

The use of quinine and other recognized febrifuge
is not giving satisfaction: their relief is only
temporary. In several cases that have come under
our observation we have always found that fever
has recurred with greater virulence after the use of
the recognised English febrifuges. In all such cases
we have uniformly prescribed Asvinivati with great
success, the fevers never recurring in almost all
cases. In the few cases where there was a relapse,
a few more doses were enough to stop them forever.

Duraiswami Aiyangar, a renowned Ayurvedic physician, also suggested sudarśana cūrṇam, pad̄ōāthi cūrnam and pañjatiththakvāda instead of quinine for treating malaria fever (Aiyangar, 1918c, p. 142). Along with medical advice, he published perspectives of practitioners of western medicine such as Dr. Rasul, Captain Patrick and Sub-Assistant Surgeon A Nanjunda Aiyar on malaria and quinine in his Tamil medical journal Vaidya Kalanidhi. He also translated into Tamil and published in his journal articles originally published in western medical journals like Antiseptic, Critic and Guide, Practical Medicine regarding the negative impacts of quinine (Aiyar, 1918, pp. 140-142). Thus, most of the practitioners of indigenous medicines wrote against western medicine and projected its negative impacts in the public sphere to counter the hegemony of western drugs in medical market along with creating niche for their respective medicines. However, it cannot be concluded that all practitioners of indigenous medicines were negative in prescribing quinine.

Practitioners of indigenous medicines took up the idea of race and territoriality to argue for the efficacy of their drugs. They constructed 
indigenous body as a separate type which differed from the European body type and promulgated that indigenous medicines which were the product of Indian soil, were better suited to Indian body type than medicines produced in 'alien' temperate European soil (Varier, 1913, pp. 97-100). For example, P S Varier pointed out in his journal Dhanvanthari about indigenous and western drugs. The article, entitled, Pāscātya Vaidyamum Purvastya Vaidyamum (Western medicine and Indigenous medicines) portrayed that the drugs of Ayurveda were discovered on the basis of Indian bodily temperment and climatic conditions of India but western medicine was produced based on European's bodily nature and their climatic conditions. So western medicine was suitable for the Europeans but not for the Indians. Further, western drugs which were prepared based on diseases but never took the account of prakrti and dosa levels of patients. If the Indians want to be in good health and wellbeing, they had to adopt Ayurveda which would be apt to Indian bodily temperment and in conformity with Indian climatic conditions producing less side effects (Varier, 1913, pp. 97-100). Similarly, Vaid Ponnusamy Pillai from Kumbakonam defined medicine that it was a disease alleviating substance which should be prepared after analysing the condition of bodily temperament, environment of the place, lifestyle, diet practices and stages of disease. Medicine of one country would not be suitable for the diseases and body of another country. Therefore, indigenous drugs which would prepare with the natural products grown in Indian soil, would be only suitable to cure the diseases of the Indians (Pillai, 1928, pp. 9-10).

Practitioners of indigenous medicines attacked western medicine as catalogue or advertisement as it was prescribed irrespective of bodily temperament. Pandit Narayana Iyengar (1925d, pp. 1-3) in his article 'Marundu Seibāgam' (A Preparation of Drugs) quoted that practitioners of western medicine never try to understand the different types of body and conditions of diseases.
Without having knowledge of preparation and ingredients, they prescribe drugs from the catalogues of medical stores unlike the indigenous who prepare medicines themselves after analysing bodily temperament and disease conditions of patients. Pandit Duraiswami Aiyangar and Kaviraj Gananath Sen projected European drugs as mixture of animal products and alcohol. They showed that medicines such as fel bovinum, virol and cod liver oil are produced from beef, bone marrow and fish respectively. They condemned the use of western medicine from a religious standpoint and promulgated that ingredients forbidden by Hindus were part of western medicine which ultimately spoiled the sātvik life of Hindus (Sen, 1915, pp. 98-100 and Aiyangar, 1921b, pp. 125-126).

The dietetic regimen was also addressed by practitioners of indigenous medicines prominently in the debate. They propagated that indigenous drugs were only suitable to the Indian conditions because it evolved in India, was adapted to fit the needs of the Indian people and blends with the social, cultural and religious practices of the country. They pointed out that the western medicine does not develop concepts on dietetics. According to P S Varier practitioners of western medicine hardly consider the dietetic regimen while ayurvedic physicians gave great importance. Ayurvedic physicians considered the merits and demerits of all food item in its different forms and conditions, and of every one of our actions. In particular, ayurvedic physicains were very keen on the conditions of time, vitality, place, seasons, habits and the age of the patients while suggesting diets. But, practitioners of western medicine considered diet on the basis of chemical compostion of the ingredients which hardly yield any fruitful results (Varier, 1913, pp. 97-100).

These sort of attacks on western medicine intensified after the publication of the report of Indigenous Drug Committee, prepared by Dr. M C Koman for the Madras Government. 
Practitioners of indigenous medicines and national journals condemned the report of Koman as a destroyer of indigenous 'systems'. Dravida Vaidya Mandal and Madras Ayurveda Sabha jointly prepared a report against Koman report and severely questioned the authenticity of each and every aspect of the report of Indigenous Drug Committee.

\section{Discussions on Diagnostic Techniques}

One of the important aspects in the discussion between practitioners of indigenous and western medicines was diagnostic techniques. Practitioners of western medicine attacked diagnostic methods of indigenous medicines, while projecting the superiority of western clinical and technical developments. They explained their diagnostic techniques on the scientific basis. They asserted that diseases could be diagnosed accurately only with the help of scientific instruments like thermometer, microscope, X-rays and so on and simultaneously attacked techniques of indigenous medicines as unscientific. For instance, Dr. C Krishna Reddy said that western medicine only had the capacity to find microorganisms with the help of scientific instruments. He, further, proceeded that for example, Tubercle bacilli which was responsible for tuberculosis, could be seen by the microscope. He attacked that practitioners of indigenous medicines simply checked hands and eyes of patients and prescribed drugs as if to understand the diseases perfectly but it was not true (Reddy, 1915, pp. 49-51). In this context, practitioners of indigenous medicines ridiculed practitioners of western medicine as technological dependents. Physician S S Anandam (1928, pp. 29-34) reciprocated in his article, entitled, Ké $\ln \bar{a} t \underline{t} u$ Maruthuvamum, Mèlnātțu Maruthuvamum (Oriental Medical System and occidental Medical System) as follows:

Western physicians are technological dependents. They are not able to diagnose diseases without the instruments. For instance, they depend on thermometer and stethoscope to know the temperature of the body and heartbeat. If they fail to use them, they are not able to find out the diseases. But indigenous physicians are independent and they diagnose diseases perfectly by just using their own fingers. Indigenous physicians understand the place of diseases i.e. heart, lungs, pancreas, kidney by analysing symptoms of pulse. Besides, Allopathy doctors can diagnose diseases only after testing the blood samples whereas indigenous physicians simply find out diseases by means of eight diagnostic techniques. When Allopathy physicians adopt amputation for fractures, indigenous physicians join the broken parts of body by external and internal drugs.

Besides, Kaviraj Gananath Sen also stated that the army of doctors trained in western medicine with the paraphernalia of costly laboratories and scientific instruments were, in the field of medical practice, not half so scientific as they were expected to be. It was a strange irony of fate that common sense and science go ill together among them. Whilst the use of unaided sense of the medical man was fast giving place to scientific methods, the cost and confusion (of the diagnosis of the case) of the poor sufferer was daily increasing. The majority of patients could not be diagnosed without costly laboratory aid. The doctor and the patient were alike duped by patent medicine mongers from the west (Mukerjee and Sen, 1928b, p. 86). Likewise, P L Jha compared western medicine with Ayurveda and brought out the superiority of the latter regarding the diagnostic and curative techniques:

The modern scientists are unable to recognize the disease process at the early stage (prakopa stage) and do anything rationally for the good of the patient. But, the Ayurvedic physicians can treat the patient rationally and check the further progress of the disease even in this stage... it is no doubt true that the diagnostic methods of Ayurveda are mostly clinical in contradistinction to laboratory methods of western medicine, whose ever increasing complexity is fast becoming the despair of many of our modern-day practitioners of the west. Not that Ayurveda has nothing corresponding 
to the western laboratory methods, but its genius, as that of Hindu thought generally, is to train the senses and the mind of the observer himself rather than perfect a machinery external to the observer (Usman, 1923, p. 64).

A Lakshmipathi (1923, pp. 2-4) wrote an article entitled 'Ayurveda Sambiratāyattịn Rōga Nitchaya Vidānam' (The Diagnostic Techniques of Ayurveda) on diagnostic methods of Ayurveda in his journal Sri Dhanvantari, indicating that Ayurveda had the fundamental diagnostic techniques which stands in scientific standards. These techniques were discovered after the scientific research by ancient Risis. These techniques were being used from the remote past to diagnose diseases by the generation after generation in this country. But, practitioners of western medicine attacked these techniques without understanding their 'tattva' properly.

Usman Committee Report quoted the statement of James Mackenzie about the defects of diagnostic methods of western medicine published in indigenous medical journals. James Mackenzie pointed out vital defects of modern system like the failure to assess the prognostic value of every diagnostic feature and the consequent bungling in laying down a truly adequate and scientific line of treatment. The exaggerated importance attached to the laboratory methods of diagnosis, to the detriment of the clinical, with the result that diagnosis in western medicine was fast becoming a hopelessly and even impossibly complex achievement of an ever increasing number of super-specialists and laboratory experts of all kinds (Usman, 1923, pp. 53-54). Thus, practitioners of indigenous medicines strived to project the superiority of their diagnostic methods and, at the same time attacked the diagnostic techniques of western medicine and ridiculed practitioners of western medicine as technology dependent. However, gradually, Ayurvedic physicians also adopted scientific tools like thermometer and X-rays for their diagnosis.

\section{Reinvention of Ancient Surgical Tradition}

The contest for hegemony between practitioners of indigenous and western medicines did not prevent the exchange of knowledge. Practitioners of indigenous medicines understood their lack in the branch of surgery and anatomy. Fundamental criticism of practitioners of western medicine on indigenous medicines was lack of knowledge of surgery and anatomy that helped them to marginalise indigenous medicines as outdated and unscientific. Though surgical knowledge was embedded in the early writings such as Suśruta Samhita, the knowledge and practice of surgery had eroded gradually from the indigenous medical traditions. H H Wilson (1864, pp. 270-271) stated:

The divisions of the science (i.e. Ayurveda) thus noticed, as existing in the books, exclude two important branches, without which the whole system must be defective - Anatomy and Surgery. We can easily imagine, that these were not likely to have been much cultivated in Hindustan, and that local disadvantages, and religious prejudices, might have formed very serious impediments to their acquirement. Something of the former might be accidentally picked up by the occasional inspection of bodies, either brutal or human, which happened to be exposed... In the absence of anatomy, of course, little was to be looked for in surgery; and it has been taken for granted that, whatever might have been the character of medical science, amongst the Hindus in former days, an almost utter ignorance has always prevailed on the subjects most essential to its perfect possession and practical application.

Western medicine established its superiority and authority over indigenous medicines with the help of its surgical skills. To become scientific and legitimate medicine, there was a necessity to assimilate the knowledge and skills of western medicine particularly in the branch of surgery and anatomy. Indigenous physicians like P S Varier, Pandit Gopalacharlu, Jamini Bhusan Roy, S S Anandam, Pandit Narayana Iyengar, Pandit 
Duraiswami Aiyangar and others reinvented ancient surgical tradition and selectively adopted western surgical thereby hybridising their practices. They borrowed the technical terms and pictographs of surgical instruments of western medicine in their texts. Pandit Duraiswami Aiyangar, Pandit Narayana Iyengar, Pandit Gopalacharlu, A Lakshmipathi and others continuously wrote about ancient surgical knowledge in their respective journals such as Vaidya Kalanidhi, Vaidya Chandrika and Sri Dhanvantari. Pandit Duraiswami Aiyangar (1918a, pp. 110-113) wrote extensively about ancient surgery in his articles, entitled 'The Ayurvedic method of Surgical Treatment'. He explained surgical and bandaging methods and pointed out that surgery had been divided into three phase such as pre-operative treatment (pūrvakarma), treatment (pradhānakarma) and post-operative treatment (pascātkarma). Pürvakarma indicated the preparations of patients and instruments before operation; pradhānakarma meant the surgery; and pascātkarma was the treatment after the surgery. Surgery had been classified into eight types such as excision (cedyam), incision (bhedyam), scraping (lekhyam), puncturing (vedhyam), probing (esyam), extraction (āhāryam), draining (visrāvya) and suturing (sivya). Furthermore, he projected that Suśruta Saṃhitā mentioned antiseptics, anaesthetics and different types of bandages. Ancient Indian physicians knew fifteen different types of bandages such as kōsam, svastikam, mutōli, sinam, tāmam, anuvelvitam, kamvā, vibandam, sattakikā, vidānam, utsaingam, kōbaṇam, yamagam, maṇdalam and pañsāinki but presently, practitioners of western medicine knew only three types of bandages such as triangular, roll and special bandage. Moreover, when the whole world was still in primitive stage, indigenous surgeons knew about rhinoplasty, abdominal surgery, cataract, and lithotomy (Aiyangar, 1918b, pp. 125128). He concluded that these aspects indicated superior knowledge of ancient Ayurvedic physi- cians which could not be competed even by modern physicians. Apart from writings, he gave pictures of ancient surgical instruments in his book Aștāinga Hṛdayam. Likewise, Kaviraj Jamini Bhushan Roy projected the superiority of surgical practices of Āryans in the Usman Committee enquiry. He said that in both branches of the Âryans stock, surgical practice as well as medical reached a high degree of perfection at an early period. He described the quality of surgical instruments mentioned in Suśruta Samhitā. They had good handles and firm joints, well-polished and sharp enough to divide hair; they were perfectly clean, and kept in flannel in a wooden box (Usman, 1923, p. 13). He, further, added about the superior surgical skills of ancient indigenous surgeons:

\begin{abstract}
Wounds were divided into incised, punctured, lacerated, contused, etc. Cuts of the head and face were sewed. Skill in extracting foreign bodies was carried to a great height, the magnet being used for iron particles under certain specified circumstances. Inflammations were treated by the usual antiphlogistic regimen and appliances; venesection was practised at several other points besides the bend of the elbow; leeches were more often resorted to than the lance; cupping also was in general use. Poulticing, fomenting, and the like were done as at present. Amputation was done now and then notwithstanding the want of a good control over the haemorrhage... There was a plastic operation for the restoration of the nose, the skin being taken from the check adjoining, and the vascularity kept up by a bridge of tissue. The ophthalmic surgery included extraction of cataract. Obstetric operations were various, including Caesarian section and crushing the foetus (Usman, 1923, p. 13).
\end{abstract}

Kaviraj Gananath Sen reply to the Usman Committee enquiry reflected views of practitioners of indigenous medicines who were willing to syncretise indigenous and western medicines for well-being of the public (Usman, 1923, pp. 3-4). Pandit Duraiswami Aiyangar and P S Varier published illustrations of surgical instruments in their text books and journals respectively. Likewise, Girindranāth Mukhopādhyāya (1913) 
published exclusively two volumes for Hindu surgical instruments, entitled, The surgical Instruments of the Hindus but all the pictures were borrowed from western medical texts because there was no pictographic presentation of surgical instruments in the ancient indigenous medical texts.

Some practitioners of indigenous medicines adopted the surgical skills and instruments from western medicine as their right. They claimed that present surgical skills of western medicine were the evolution of ancient Ayurvedic surgical skills which were taken from India to Europe via Arabs. Pandit Narayana Iyengar (1925a, p. 3) pointed out that surgical instruments were appropriated from indigenous medicines by practitioners of western medicine like nagasastiram (nailpairer); añcitākram (abscess-knife); artatāram-(paget's knife); pratākram (scalpel); kābatram (saw); kuḍ̄arikā (axe-shaped); varēhimugam-(teocar); maṇdalākram (spoon) and others. He projected that these instruments were rechristened by practitioners of western medicine after the appropriation. Sarayu Prasad (1920, pp. 73-80), Chairman of the Reception Committee of the eleventh session of All India Ayurvedic Conference, stated that the modern surgical knowledge of Europe was nothing but only ancient Ayurvedic surgical skill. Likewise, Jamsedhji Jivan (1926, pp.20-22) also reflected the same opinion that the Europeans took ancient knowledge of Hindus and fused it with their system.

\section{Selective Adoption and ReInTERPRETATION OF MODERN AnATomy}

Anatomical knowledge of indigenous medical texts varies from modern anatomy. Different sorts of body types such as medical body, yogic body, tantric body, sacrificial body, Upanicad body and Jain body were projected in the texts of pre-modern India which indicate that there was no singular concept of body in indigenous texts (Dasgupta, 1991, p. 433; Wujastyk, 2009; Bhattacharya, 2009). For instance, measurement of the body is different in Suśruta and Caraka Samhitās. Suśruta scaled the standard length of a body as 120 angulas whereas Caraka referred to 84 angulas. Besides, Suśruta explained bodily process on the basis of marmam (Lal, 1911, pp. 187-188 and Wujastyk, 2003, pp. 242-244). Ayurvedic medical body evolved by incorporating different types of body concepts from time to time. For example, yogic concept of chakras was added into Ayurvedic medical body during the second millennium after Christ (Wujastyk, 2009). Though different conceptual bodies are described in indigenous medicines, a body frame is dominated by the humours - vital fluids, vāta, pitta and kapha and network of channels. The primary features of the body are three dosas (humours), dhätus (body tissues) and malās (wastes). Three doṣa of the body actively work with dhätus and malās. Further, Sāraingadhara Samhitā, an Ayurvedic text of the $14^{\text {th }}$ century, developed indigenous body and itemised parts it as follows: There are 7 body tissues (dhātus), 7 subsidiary tissues (upadhātus), 7 impurities of body tissues (dhātumalās), 7 membranes (tvac), 7 receptacles (āsayas), 3 humours (doșa), 900 sinews (snāyus), 210 ligaments (sandhi), 500 muscles (māmsapesi), 20 extra ones for women, 16 tendons (kandara $\bar{a}), 10$ orifices of male body and 13 orifices of the female body (Wujastyk, 2003, pp. 270-274). Although, indigenous medical literature explained bodily activities on the basis of tridosa theory and organs in its own terms, the modern notions of anatomy and physiology of Harvey were totally absent in these texts. According to scholars, the body in Ayurveda was understood well by empirical examination and not by surgical methods (Zysk, 1986 and Wujastyk, 2009). In particular, acquisition of anatomical knowledge by means of sacrifice of animals or observation on decomposing corpse. Causation of disease was 
assumed on the basis of derangement of tridosa rather than organ localisation of disease which was prominent in the case of western medicine (Zysk, 1998, pp. 34-35 and Zimmermann, 2018). This state of anatomical knowledge of practitioners of indigenous medicines were criticised by practitioners of western medicine and they strived to marginalise indigenous medicines. For instance, Peter Breton (1825, p. 1), English East India Company's Surgeon, observed about Indian anatomical knowledge as follows:

\begin{abstract}
They have no distinct word for nerve and therefore call it Nus, Asub, Shirra, etc. in common with Ligaments and Tendons...they know not the distinction between an Artery and Vein and consequently the appellation of Rug and Shirra are indiscriminately applied to both. The Hindee word Rug and Shirra according to the Soosrut, a Sanskrit work on Anatomy and Pathology, means blood vessels or tubular vessels of any kind.
\end{abstract}

After severe criticism and marginalisation, practitioners of indigenous medicines started to reformulate their knowledge along the standards of Western medicine to compete against the hegemony of western medicine. They selectively adopted and adapted the anatomical knowledge of western medicine to make Ayurveda modern and scientific.

Physicians like Muralidhara Sharma (Royal physician of Farrukhabad), Kaviraj Gananath Sen and S R V Das imported western anatomical knowledge and illustrations. During the early decades of the twentieth century, syncretic Ayurvedic texts with terms and illustrations of modern anatomy were printed more in Sanskrit and vernacular languages. P S Varier published two important syncretic books on anatomy in Sanskrit language such as Aștāngasārīram (1925) and Brhacchārīram (1942) and wrote these aspects in his Malayalam journal Dhanvanthari as well. Kaviraj Gananath Sen published a book, entitled, Pratyaksha Sārīram and Pandit Duraiswami Aiyangar continuously wrote and illustrated the modern anatomy with Sanskrit terminology in his Tamil medical journal, Vaidya Kalanidhi. S R V Das (1923, pp. 199-204) wrote articles, entitled 'Mānida Tēgattin Marmangal' (Secrets of Human Body), in his Tamil medical Journal Āyulvedam about anatomy and physiology which combined modern anatomy with Ayurvedic terminology. But when analysing these writings, they reflected 'epistemic duality' of their knowledge adoption. The process of reformulation of anatomical knowledge was not activated as projected by Jayanta Bhattacharya who argued that practitioners of indigenous medicines adopted modern anatomy completely. The texts published by practitioners of indigenous medicines reflected two methods that were followed. On the one hand, they borrowed modern terminologies and illustrations and on the other hand, reinterpreted Ayurvedic concepts and terms to correlate to modern anatomy (Bhattacharya, 2009). For example, Duraiswami Aiyangar (1915, p. 38) published modern anatomical illustrations in his journal and at the same time, tried to equate Ayurvedic Sanskrit terms with modern anatomical terms. He denoted the bones of body as 'Lalā (frontal bone); Pidarelumbu (occipital bone); Sañkāstti (temporal bone); Pārsuvakabālangal (parietal bones; Jarjarāstti (ethmoid bone); Vamsāstti (spinal column) and Susumnākāndam (spinal cord).' Though the meaning of these Sanskrit terms used by ancient physicians is still uncertain, Ayurvedic physicians in the twentieth century reconstituted these terms to match modern anatomy. Some practitioners of indigenous medicines propagated that the Europeans appropriated Ayurvedic anatomical nomenclature to indicate organs while some found new vocabulary in Sanskrit language to denote modern anatomical terms. By the way, they challenged the charge of practitioners of Western medicine that Ayurveda does not have the knowledge of anatomy. Pandit Narayana Iyengar (1925a, p. 3) had given a list of appropriated anatomical terms of Ayurveda in modern anatomy and questioned 
practitioners of western medicine regarding the criticism of absence of anatomy in Ayurveda. He listed as follows: 'Hirut (heart); Parihirudayam (pericardium); Pari Ostigam (peri osteum); Karmamāthru (thermometer); Splegha (spleen); Klōma (lung); Kanda (gland); Swetha (sweat) and Karmajanitha (thermogenesis).' Further, he said that likewise, more Ayurvedic terms were appropriated by westerners to indicate the organs of the body. So how could they defame Ayurveda for the absence of anatomical knowledge when it already had so many terms for organs? Kaviraj Gananath Sen continuously published the availability of Sanskrit anatomical nomenclature equivalent to modern anatomical terms in The Journal of Ayurveda by which he countered views about lack of anatomical knowledge in Ayurveda.

Apart from these aspects, practitioners of indigenous medicines strived to reinterpret Ayurvedic terms in the light of modern anatomy through which they contested the scientific authority of western medicine and located indigenous medical theories within the scientific credentials (Zimmermann, 1999). For instance, tridosa which is fundamental to indigenous medicines, was continuously (re) interpreted by indigenous physicians in a different manner. A number of physicians tried to equate tridos $a$ with various aspects of modern anatomy in a number of ways such as humoral, hormonal and metaphysical. For instance, Kaviraj Gananath Sen who published a text on anatomy, entitled, Sharir Parichay (Introduction to Anatomy) in which he borrowed diagrams and figures from the different anatomical texts of western medicine. He reinterpreted ancient Ayurvedic anatomical terms in the light of modern anatomy. Besides, he has given a new connotation to Sanskrit terms and correlation with modern concepts. He constructed traditional philosophy of tridosa in the light of modern anatomy and physiology (Sen, 1924 and Bhattacharya, 2008). He pointed out that western physicians misunderstood the concept of humours vāta, pitta and kapha as wind, bile and phlem. Further he stated that the theory of $v \bar{a} y u$, pitta and kapha was also a great discovery, which unfortunately has been much misunderstood by Western Scholars judging by the wrong irresponsible translation, rendering these terms as 'wind, bile and phlegm.' The proper explanation of this theory would take up a treatise by itself, but let me observe here in passing that the word vāyu does not imply 'wind' in Ayurvedic literature, but comprehends all the phenomena of motion which come under the functions of life-or to be more explicit-functions of life as manifested through cell-development in general and through the central and sympathetic nervous systems in particular; that the word pitta does not essentially mean bile but signifies the functions of metabolism and thermogenesis or heat production comprehending in its scope, the process of digestion, metabolism, coloration of blood and formation of various secretions and excretions, which are either the means or the ends of tissuecombustion, and that the word kapha does not mean Phlegm but is used primarily to imply the functions of cooling and preservation (thermotaxis or heat-regulation) and secondarily the production (and products) of the various preservative fluids, e.g., Mucus, Synovia etc., which are the manifest forms of that function (Sen, 1916, pp. 20-22 and Shah, 2017, pp. 452-453). Pandit Narayana Iyengar (1926b, pp. 2-8) conjoined tridosa with vitamins by analysing their deficiencies and impact. He said that according to western medicine, when the level of vitamins $\mathrm{A}, \mathrm{C}$ and $\mathrm{B}$ reduced, it created diseases like night blindness, scurvy and beriberi. Likewise, the derangement of vāta, pitta and kapha in body was fundamental to the causation of diseases. Moreover, practitioners of western medicine affirmed vitamins as building blocks of the body which was also the case in tridosa. Further, he propounded that the characteristic features of kapha, pitta and vāta were identical with Vitamin $\mathrm{A}, \mathrm{C}$ and $\mathrm{B}$ respectively. P S Varier projected three 
dhātus as living cells of protoplasm of modern anatomy. He explained the nature of three dhätus and correlated them with the activity of protoplasm. He wrote in his Malayalam medical journal Dhanvanthari that

\begin{abstract}
It is easy to find out that a living cell of the protoplasm is a combination of the three dhätus in their natural form, because it has all the function ascribed to these dhâtus. It is these cells, the minute forms of dhätus, which naturally build the body by dividing and multiplying themselves... If that is so, one cannot but agree that the membranes called blastoderm (balisthadharmā) originating from the fertilized ovum (kalala) by division, multiplication and cohesion, contain all the dhātus. Its subdivisions also show the predominance of some dhātu or the other. Fortunately, the latest theories of western Embryology agree with these principles, because the ectodermic (bāhyabalisțha), endodermic (āntarabalistha) and mesodermic (madhyamabaliștha) membranes generate those parts of the organism in which vāyu, māyu and valāsa of Āyurveda predominate in that order (Varier, 2012, 27-38).
\end{abstract}

Practitioners of indigenous medicines tried to locate the humoral concept within the framework of western medicine but it reflected confusion and ambiguity. Indigenous physicians conjoined concepts of indigenous medicines with a number of aspects of western medicine which indicates their effort of reframing the fundamentals to claim scientific authority.

'Ojas' is another important substance equated with modern anatomy by Ayurvedic physicians during the revitalisation movement. Ayurvedic literature have different conceptual aspects for ojas in pre-modern India. For instance, Chakrapani Datta, commentator of Caraka explained two kinds of ojas whereas Suśruta gave single ojas and qualities also vary one from another. In the context of Chakrapani Datta, ojas was linked with bala (physical force) and slesma (phlegm). But, Suśruta Samhita mentioned that ojas is a single and undivided substance. Ojas and bala are the same. Likewise, a number of views on ojas were written time and again in Ayurvedic literature. For example, Dalhana, commentator of Suśruta Samhita, rejected the concept of Suśruta regarding ojas. He pointed out that ojas and bala were two different parts of the body rather than identical as mentioned by Suśruta. Further, he stated that ojas, being a substance that possessed the properties of guna whereas bala is a physical force of the body. Though there are different views on ojas, generally, it is understood as an essential substance to all dhätus and source for unconstrained functioning of all organs of the body. It is always connected to the body strength (bala) and slesmā. Heart is the seat of ojas. It is said that if ojas diminished in a body, one was weak, afraid and would finally die (Meulenbeld, 2008, p. 160). During the revitalisation movement, new feathers were added to the concepts of ojas. Practitioners of indigenous medicines equated ojas with different elements of western anatomy and added new aspects to the concept of ojas. For example, Pandit Subbaraya Sastri correlated 'ojas' with modern Albumen. He pointed out that both had similar characters like spreading in the whole body, gluey in nature and part of blood. When both levels would decrease in blood, it would lead to death. Thus, he concluded that 'ojas' was nothing but modern 'Albumen' (Sastri, 1921, pp. 53-56). Apart from Albumen, physicians connected other anatomical parts and functions to ojas. Prabhanjan Acharya equated ojas to vitamins, glycogen, pituitrin, internal secretions of ovaries and testicles and the prostatic secretion. Likewise, Kanak Prasad and Asvini Kumar Sarma connected ojas with semen and sexual hormones. They equated ojas with sukrasāra (the essence of semen), sukramala (the impurity derived from semen), sukropa dhātu (the upadhātu of semen), sukrasnehabhāga (the fatty part of semen), sukrajanaka (that which generates semen), testosterone, phlegm, rasayoga, blood, and the para tejas of the seven dhätus (Meulenbeld, 2008, p. 165). According to Jan Meulenbeld (2008, p. $165)$, the equalisation of ojas with semen and sexual hormones were absent since Vedic times. 
But, practitioners of indigenous medicines inserted new aspects to ojas in the process of reinventing medical tradition.

Similarly, other aspects of indigenous medicines were conjoined with western anatomical concepts. Ashutosh Roy tried to correlate the modern anatomy and physiology of nerves system with $n \bar{a} d i$ system of indigenous medicines. He projected that even western medicine did not enter deep level that was reached by ancient Hindus. He wrote an article, entitled, 'The Nervous System of the Ancient Hindus', in The Journal of Ayurveda, regarding this aspect:

The descriptions are often allegorical and not quite accurate, when compared with those of modern anatomy, and various metaphysical functions are ascribed to which we moderners are quite unaware, for modern medicine has not studied its functions in detail in the higher intellectual and mental sphere. But what strikes us with wonder is that the ancient Hindus at such an early period tried to study this most delicate and intricate system of the human body scientifically...Even modern medicine, with its animal experiments, its delicate staining methods, its post-mortem records could not fully study the functions of its various parts, for example the big silent area of the brain and that in the spinal cord (Roy, 1930, p. 297).

He gave a vivid picture of the body of the yogic system such as 72,000 nādis and cakras. He propagated these aspects as minute details of the nervous system which were absent in modern anatomy. Likewise, S S Anandam (1928, pp. 2931) also noted the superiority of nādi system of indigenous medical 'systems' as follows:

Our Siddhas found that there are 72,000 nādis in the whole body which are controlled by prominent ten nădis out of which three became important viz. eda, pingala and susumana. By understanding these three nădis, the physicians realise the conditions of the body without seeing the internal organs. When Western physicians give importance to sthūla śarìra, Siddha physicians concentrate on both sthūla and sukșama śarīra. While the ordinary humans like Western physicians are not able to move beyond the physical body, the Siddha physicians realise the problems in eternal body as well. Besides, when Western physicians fail to find the causation of diseases after analysing the physical body, Siddha physicians exactly pointed out problems because they were analysing physical and eternal body. Very important aspect of Siddha medicine is that Siddha physicians can fix whether the diseases can be curable or not while western physicians stumble to understand diseases.

This equation was criticised by Ayurvedic physicians and scholars like K G Natesa Sastri and Rahul Peter Das respectively. Rahul Peter Das explained the complexities of the commensuration of Ayurvedic terminologies with modern medicine and also projected the problems in the process. According to Rahul Peter Das, indigenous physicians like Gananath Sen equated specific terms in ancient medical texts with the concept of western medicine without critical examination. He meant that rejecting a large part of the actual anatomy of the ancient Indian texts as spurious and only that accepted as an authentic part of the ancient tradition which was in keeping with modern western medicine as it was at the truth of twentieth century. He ridiculed that these physicians discredited to the indigenous medical system in the name of claiming scientificity (Peter Das, 2003, pp. 5-7).

When revitalising indigenous medicines to contest the hegemony of western medicine during the late nineteenth and the early part of the twentieth century, some indigenous physicians projected the availability of anatomical knowledge in ancient Ayurvedic literature and others attempted to commensurate Ayurvedic anatomical terms with western medicine. They selectively adopted certain aspects of modern anatomy such as terminologies, physiology and visual illustrations in their publications. They syncretised anatomical knowledge of indigenous and western medicines and equated fundamental aspects of indigenous medicines with western anatomy to legitimise their medicines. This 'epistemic duality' was profoundly reflected in printed publications of the early part of the twentieth century which were mostly in Indian languages, including 
Sanskrit. ${ }^{1}$ Further, this selective adoption and reinterpreting process extended the frontiers of a new vocabulary in Indian languages for the terms of modern anatomy to manifest the new medical knowledge. While modernising indigenous medicines by equating the terms and concepts with western medicine, the importance of indigenous medical concepts moved from sukșama śarīra (subtle body) to sthūla śarīra (physical body). Furthermore, a spatial shift in perception from macrocosmic-microcosmic arrangement of the 'Indian' body to the circumscribed, threedimensional anatomical space, and a shift from impurities in whole body to modern notion of organ localisation of disease (Bhattacharya, 2008b, pp. 155-156).

\section{Conclusion}

The contest against marginalisation of practitioners of western medicine was multifarious and ambivalent. Western medicine was not so powerful in the social sphere at the end of the colonial period, however it was very influential in the political sphere (Arnold, 1996, pp. 10757078). Western medicine acted as a 'tool of empire' and it was officially preferred and patronised by the colonial government which followed a stepmotherly attitude towards indigenous medicines. The colonial state marginalised indigenous medicines in the areas of financial support, institutionalisation, employment, recognition, legitimacy etc. The practitioners of western medicine criticised and propagated indigenous medicines as 'backward', 'unscientific' and 'dangerous' medicines. Indigenous physicians started revitalising and competing with western medicine in the public sphere. Both sides took the help of printing media to counter the process. In this struggle, there were multifarious responses from practitioners of indigenous medicines to the criticism of practitioners of western medicine. For instance, some physicians rejected western theories and methods, some strived to locate indigenous theories within the framework of western medicine, some were dispensing western drugs for their patients, some criticised western drugs as dangerous and so on. Moreover, the concepts of indigenous medicines were reinterpreted on the basis of necessity of time. Indigenous medical terms and theories were reframed according to western terminologies and standards. Some concepts and theories were mutually accepted. Even though it seems that practitioners of indigenous medicines challenged the hegemony of western medicine explicitly, they adopted the various premises, norms, standards and scientific concepts of western medicine in order to term it as a rational-progressive and scientific. In a way, the practitioners of indigenous medicines accepted the superiority of western medicine implicitly though they condemned and criticised western medicine in the public sphere.

The contest of indigenous physicians brought some fruitful results in changing the negative attitude of the colonial government and pushed it to take steps for the development of indigenous medicines. As a result a committee consisting of Muhammad Usman Sahib Bahadur, G Srinivasamurthi, A S Krishna Rao, U Rama Rao, A Lakshmipathi, M Subrahmania Ayyar, K G Natesa Sastri, C T Arumugam Pillai, T R Ramachandra Ayyar and A T Palmer was formed to report on the question of the recognition and encouragement of the indigenous medicines. On the basis of the recommendation of the Committee the Indian Medical School, with attached hospital, was founded on 3rd November, 1924 in Madras with four years courses in Ayurveda, Siddha and Unani. The local boards and corporations opened indigenous medical hospitals and dispensaries where practitioners of indigenous medicines were appointed. The provision of medical registration to the practitioners of indigenous medicines (Madras Medical Registration Act of 1914) was

\footnotetext{
${ }^{1}$ The term "Epistemic Duality" was borrowed from Dominik Wujastyk.
} 
amended by an executive order G.O. No. 231 P.H. dated February 2, 1933. These were indeed milestone achievements against the backdrop of western medicine and the colonial government in India.

\section{ACKNowledgement}

I would like to thank Prof. G Chandhrika (Pondicherry University), Prof. Deepak Kumar (JNU), Dr. Rick Weiss (Victoria University, Newzeland), Dr. Guy Attewell (French Institute of Pondicherry), Dr. John Bosco Lourdusamy (IIT Madras) and anonymous referee for their valuable suggestions and inputs.

\section{BiBLIOGRAPHY}

Aiyangar, D. First Aid in Accidents, Vaidya Kalanidhi, 3.2 (1915): 38 .

-. Some Suggestions to Improve the Ayurvedic System, Vaidya Kalanidhi, 8.12 (1921b): 125-126.

—. The Ayurvedic Method and Surgical Treatment, Vaidya Kalanidhi, 5.7 (1918a): 110-113.

—. The Ayurvedic Method and Surgical Treatment, Vaidya Kalanidhi, 5.8 (1918b): 125-128.

-. The Treatment of Malaria, Vaidya Kalanidhi, 5.9 (1918c): 142.

—. Vedas and Ayurveda., Vaidya Kalanidhi, 6.10\&11 (1919): 133-135.

—. Why People are Ill?, Vaidya Kalanidhi, 8.1 (1921a): 14-16.

Aiyar, A N. The Treatment of Malaria, Vaidya Kalanidhi, 5.9 (1918): 140-142.

Anandam, S S. Kēlnāṭtu Maruthuvamum, Mēlnātṭu Maruthuvamum. MaruthuvaI, 1 (2) (1928): 29-34.

Anonymous. Indigenous Systems of Medicine in India: Ayurveda, Siddha, Unani. The British Medical Journal, 4.2 (1923): 479-480.

Arnold, D. The New Cambridge History of India Vol III: Science, Technology and Medicine in Colonial India. Cambridge University Press, Cambridge, 2002.

- A Time for Science: Past and Present in the Reconstruction of Hindu Science 1860-1920.
Daud, Ali (eds), Oxford University Press, New Delhi, (1999): 156-177.

-. Colonizing the Body: State Medicine and Epidemic Disease in Nineteenth Century India. University of California Press, Los Angeles, 1993.

- The Rise of Western Medicine in India. Lancet 348, October 19, (1996): 1075-78.

Bala, P. Imperialism and Medicine in Bengal: A Social Historical Perspective. Sage Publication, New Delhi, 1991.

Berger, R. Ayurveda Made Modern: Political Histories of Indigenous Medicine in North India 1900-1950. Palgrave Macmillan, New York, 2013.

Bhattacharya, J. Anatomical Knowledge and Anatomy of the Medical Knowledge: Some (Post) Colonial Enquries. Ph. D Diss., University of North Bengal, 2008.

-. Anatomical Knowledge and East-West Exchange. Deepak Kumar and Raj Sekhar Basu (eds). Oxford University Press, New Delhi, (2013): 40-60.

-. The First Dissection Controversy: Introduction to Anatomical Education in Bengal and British India, Calcutta Science, 101.9(2011): 1227-1232.

- The Genesis of Hospital Medicine in India: The Calcutta Medical College (CMC) and the Emergence of a New Medical Epistemology, The Indian Economic and Social History Review, 51(2) (2014): 231-264.

-. The Knowledge of Anatomy and Health in Âyurveda and Modern Medicine: Colonial Confrontation and Its Outcome, ea, 1.1(2009): 1-51.

-. Encounter in Anatomical Knowledge: East and West, IJHS, 43.2 (2008): 163-209.

Breton, P. A Vocabulary of the Names of the Various Parts of the Human Body and of Medical and Technical Terms in English, Arabia, Persian, Hindee and Sanscrit, for the Use of the Members of the Medical Department in India. Government Lithographic Press, Calcutta, 1825.

Chakrabarti, P. "Neither of Meat nor Drink, but What the Doctor Alloweth": Medicine Amidst War and Commerce in Eighteenth Century Madras. Bulletin of the History of Medicine, 80.1 (2006): 1-38.

Das, R P. The Classical Ayurvedic Representation of Human Anatomy. Bertil Tikkanen and Albion M. Butters (eds). Helsinki, Finland, 2011.

-. The Origin of the Life of a Human Being: Conception and the Female according to Ancient Indian Medical 
and Sexological Literature. Motilal Banarsidas, Delhi, 2003.

Das, S. Debating Scientific Medicine: Homeopathy and Allopathy in Late Nineteenth Century Medical Print in Bengal. Medical History, 56.4 (2012): 463-480.

Das, S R V. Māniḍa Tēgattin Marmaṅgal. Āyulvedam, 1.8\&9 (1923): 199-204.

Dutt, U C. The Materia Medical of the Hindus: Compiled from Sanskrit Medical Works. Thacker Spink \& Co, Calcutta, 1877.

Ganesan, U. Medicine and Modernity: The Ayurvedic Revival Movement in India, 1885-1947, Studies on Asia, 1.1(2010): 109-131.

Goodeve, H H. The Practice of Physic: Introductory Lecture. The Calcutta Monthly Journal, 3.3 (1837): 19-26.

Gopalacharlu, D. Ayurvedic Medicines, G.R.C. Press, Madras, n.d. http://Wellcomelibrary.org/player/ b2047109 (Accessed October 09, 2015).

Gupta, B. Indigenous Medicine in Nineteenth and Twentieth Century Bengal. Charles Leslie (eds). Motilal Banarsidass Publishers, Delhi, (1998): 368-378.

Guy, A. Yunani Tibb and Foundationalism in Early Twentieth Century India: Humoral Paradigms between Critique and Concordance. Elisabeth $\mathrm{Hsu}$ and Peregrine Horden (eds). Berghahn, Oxford, (2013): 129-148.

Hardiman, D. Indian Medical Indigeneity: From Nationalist Assertion to the Global Market. Social History, 34.3(2009): 263-283.

Harrison, M. Public Health in British India: Anglo-Indian Preventive Medicine, 1859-1914. Cambridge University Press, Cambridge, 1994.

-. Medicine and Orientalism, Biswamoy Pati and Mark Harrison (eds). Oriental Longman, New Delhi, (2001): 37-87.

Hymavati, P. Religion and Popular Medicine in Medieval Andhra. Social Scientist, 21.1\&2 (1993): 34-47.

Iyengar, N. Brahmasri K.G. Natesa Sastrigaḷụaiya Maraivu, Vaidya Chandrika, 9 (8) (1947): 185-194.

—. Edu Uyarntadu, Vaidya Chandrika, 1.3 (1925b): 1-4.

—. Jvarangal, Vaidya Chandrika, 2.6) (1927): 1-4.

—. Marundu Seibāgam, Vaidya Chandrika, 1.6 (1925d): 13.

—. Swadēsha Marundugal, Vaidya Chandrika, 1.5 (1925c): $3-5$.
- Swadēsha Nōlgaḷil Kuraivu Onrumilai, Vaidya Chandrika, 2.2 (1926a): 1-3.

—. Swadēshigal Quack Allatu Mōḍavaidyarā?, Vaidya Chandrika, 1.2 (1925a): 1-5.

—. Vitamins Enra Vactuvai Pari Or NibuGar E; uthuvathaI Sāram, Vaidya Chandrika, 2 (4) (1926b): 2-8.

Jivan, J. Surgery, Vaidya Chandrika, 2.4 (1926): 20-22.

Koman, M C. Report of the Investigation of Indigenous Drugs. Government Press, Madras, 1921.

Kumar, D. Medical Encounters in British India, 1820-1920. Economic and Political Weekly, January 25, (1997): 166-170.

Lakshmipathi, A. Ayurveda Sambiratāyattin Rōga Nitchaya VidāIam. Sri Dhanvantari, 1.8 (1923): 2-4.

Langford, J. Fluent Bodies: Ayurvedic Remedies for PostColonial Imbalance. Duke University Press, London, 2002.

Liebeskind, C. Arguing Science: Unani Tibb, Hakims and Biomedicine in India, 1900-1950. Waltraud Ernst (eds). Routledge, London, (2002): 58-75.

Linschoten, J H V. The Voyage of John Huyghen Van Linschoten to the East Indies. Arthur Coke Burnell (trans). 2 vols. The Hakluyt Society, London, 1885.

Macleod, R. Introduction. Roy Macleod and Milton Lewis (eds). Routledge, London, 1989.

Megaw, J W D. The Ancient Systems of Medicine, The Indian Medical Gazette, 60 (1925): 585.

Meulenbeld, G J. History of Indian Medical Literature. Vol. 1A. Egbert Forsten, Groningen, 1999.

-. The Woes of Ojas in the Modern World. Dagmar Wujastyk and Frederick M Smith (eds). State University of New York Press, Albany, (2008): $157-$ 166.

Mukerjee, G and Sen, S. Based on False Theories. The Journal of Ayurveda, 4.4 (1927): 159.

-. Dr. Ranjit Singh and Ayurveda, The Journal of Ayurveda, 5.3 (1928b): 86 .

- Lt. Colonel Harper - Nelson and Ayurveda. The Journal of Ayurveda, 5.2 (1928a): 42.

Mukharji, P.B. In-Disciplining Jwarasur: The Folk/Classical Divide and Transmateriality of Fevers in Colonial Bengal, Indian Economic \& Social History Review, 50.3 (2013): 261-288.

Mukhopadhyaya, G. The Surgical Instruments of the Hidus with the Comparative Study of the Surgical Instruments 
of the Greek, Roman, Arabs and Modern European Surgeons. Calcutta University, Calcutta, 1913.

Orta, G. Colloquies on the Simples and Drugs of India. Sir Clement Markham (trans). Henry Sotheran, London, 1913.

Panikkar, K N. Colonialism, Culture and Resistance, Oxford University Press, New Delhi, 2009.

Pillai, S P. Pothu Makkaḷukku Oru Vēṇḍkōọl. Maruthuvan 1.1 (1928): 9-10.

Polu, S L. Infectious Disease in India 1892-1940, Palgrave Macmillan, London, 2012.

Prakash, G. Another Reason: Science and the Imagination of Modern India, Oxford University Press, Delhi, 2000.

Prasad, S. The All India Ayurvedic Conference Eleventh Session, Vaidya Kalanidhi, 7.4 (1920): 73-80.

Quaiser, N. Politics, Culture and Colonialism: Unani's Debate with Doctory. Biswamoy Pati and Mark Harrison (eds). Orient Longman, New Delhi, (2001): 317-355.

Ramasubban, R. Imperial Health in British India 1857-1900. R. Macleod and M. Lewis (eds). Routledge, London, (1988): 38-60.

Reddy, C K. The Diagnosis of Pulmonary Tuberculosis, Vaidya Kalanidhi, 3.3 (1915): 49-51.

Roy, A. The Nervous System of the Ancient Hindus, The Journal of Ayurveda, 6.8 (1930): 297.

Roy, R D. Quinine, Mosquitoes and Empire: Reassembling Malaria in British India, 1890-1910. South Asian History and Culture, 4 (1) (2013): 65-86.

Sastri, S. Albumen or Ojas, Vaidya Kalanidhi, 8.6-8 (1921): 53-56.

Sen, Gananath. Charges against Ayurved Answered, Vaidya Kalanidhi, 3.5 (1915): 98-100.

—. Hindu Medicine,Ayurvedasrama, Madras, 1916.

-. Sarir-Parichay: Purvardha, Kalpataru Ayurveda Bhavan, Calcutta, 1924.

-. The All India Ayurvedic Conference Presidential Address. Vaidya Kalanidhi, 7.5\&6 (1920): 101-103.

—. Tridōsha Tattvam, Vaidya Chandrika, 1.3 (1925): 1516.

Sen, S and Das, A. A History of the Calcutta Medical College and Hospital, 1835-1936, Uma Dasgupta (eds). Pearson Longman, New Delhi, (2011): 477-521.
Shah, N C. Some Thoughts on Hindu Medicine-An Address by Kavirāj Mahāmahopandhāya Gananath Sen, IJHS 52.4 (2017): 446-463.

Sharma, M. Indigenous and Western Medicine in Colonial India, Foundation Books, New Delhi, 2012.

Sumbramaniyam, K. The Malaria - Vishamajvaram, Vaidya Kalanidhi, 8.1(1921): 3-5.

Sushruta, The Sushruta Samhita. Kunja Lal Bhisagratna (trans). The Bharat Mihir Press, Calcutta, 1911.

Usman, M. The Report of the Committee on the Indigenous Systems of Medicines, 2 Vols. Government Publications, Madras, 1923 \& 1924.

Varier, P S. Pāschātya Vaidyamum Powrastya Vaidyamum, Dhanvanthari, 11.5 (1913): 97-100.

- Pāschātya Vaidyamum Powrastya Vaidyamum. Dhanvanthari, 11.6 (1914): 121-126.

-. Cikitsāsamgraham, P U K Warrier (trans), Arya Vaidya Sala, Kottakkal, 2012.

Wallace, F C A. Revitalization Movement. American Anthropologist, 58.2 (1956): 265-281.

Weiss, R S. Recipes for Immortality: Medicine, Religion and Community in South India. Oxford University Press, New York, 2009.

Wilson, H H. Medical and Surgical Sciences of the Hindus, Reinhold Rost (eds), Trubner \& Co, London, 1864.

Wujastyk, D. The Roots of Ayurveda: Selection from Sanskrit Medical Writings, Penguin, London, 2003.

-. Interpreting the Image of the Human Body in Premodern India, International Journal of Hindu Studies, 13 (2) (2009): 189-228.

Zimmermann, F. The Conception of the Body in Ayurvedic Medicine: Humoral Theory and Perception. Reference: https://www.slideshare.net/elsavonlicy/theconception-of-the-body-in-ayurvedic-medicine, accessed on 28/01/2018.

-. The Jungle and the Aroma of Meats: An Ecological Theme in Hindu Medicine. Motilal Banarsidas, Delhi, 1999.

Zysk, G. K. Asceticism and Healing in Ancient India: Medicine in the Buddhist Monastry. Motilal Banarsidas, Delhi, 1998.

-. The Evolution of Anatomical Knowledge in Ancient India, With Special Reference to Cross-cultural Influences. Journal of the American Oriental Society, 106 (4) (1986): 687-705. 